\title{
KONSEP SISTEM SINKRONISASI ENERGI: UPAYA SISTEMIK OPTIMALISASI SUMBER DAYA PERGURUAN TINGGI
}

\author{
Oleh: \\ Budi Astuti \\ Universitas Islam Indonesia
}

\section{A. PENDAHULUAN}

Sumber keunggulan kompetitif yang berkelanjutan pada suatu organisasi adalah inovasi teknologi proses dan produk. Perguruan tinggi sebagai organisasi pendidikan dalamkiprahnya sangat dipengaruhi oleh kualitas dari sumber daya yang dimilikinya terutama sumber daya manusia. Sebagai institusi pendidikan maka pengelolaan yang berkaitan dengan pemanfaatan potensi pengetahuan dan ketrampilan yang dimiliki menjadi sangat penting, dikarenakan sumbangannya dalam melahirkan inovasi produk dan proses yang pada gilirannya akan menentukan tingkat keberhasilan kinerja organisasi. Oleh karena itu kebutuhan akan optimalisasi sumber daya menjadi perlu untuk dilakukan agar keinginan peningkatan kualitas serta pemanfaatan kapasitas yang tersedia menjadi efisien dan efektif.

Salah satu upaya yang dapat dilakukan oleh organisasi pendidikan adalah melalui sinkronisasi kekuatan yang dimiliki oleh setiap subsistem dalam organisasi, sehingga dapat mendorong munculnya manfaat yang lebih besar dari pada tiap subsistem bekerja sendiri-sendiri. Kinerja suatu organisasi sangat ditentukan oleh sumber daya yang dimiliki baik sumber daya tangible maupun yang intangible. Agar penggunaan sumber daya menjadi optimal maka sinergi perlu dilakukan, dan sinergi yang relevan dengan dengan kegiatan pendidikan adalah share know-how. Aktivitas berbagi dan penciptaan pengetahuan yang dinamis adalah melalui pembelajaran. Pemikiran kreatif dan inisiatif yang bearasal dari banyak manusia/karyawan akan memungkinkan kecenderungan lebih baiknya gagasan, keputusan, pelaksanaan, mutu produk dan kinerja organisasi.

\section{B. PERGURUAN TINGGI SEBAGAI KNOWLEDGE CREATING COMPANY}

Organisasi di dalam lingkup knowledge economy pada umumnya akan menjadi lebih ramping, datar, lebih pintar, dan lebih fleksibel. Smarter Organization dicirikan dari semula merupakan penghasil barang-barang dan jasa menjadi organisasi a knowledge producer, dengan kriteria efisiensi produksi ditentukan seberapa jauh hubungan dan integrasi sumber daya pengetahuan yang tersebar. Peran manajemen dari semula melakukan monitoring dan pengawasan karyawan dan proses fisik menjadi manajemen pengetahuan (Jones, 1999:155). Dari people management menjadi knowledge management. Tugas manajemen adalah memberikan suatu cara memproses manajemen. Sehingga peran manajemen adalah: pertama, adalah melakukan pemantauan dan pengawasan terhadap pekerja dengan tingkat ketrampilan tidak tinggi. Kedua, adalah berkaitan dengan manajemen strategik yang berperan membawa pergeseran dari mengelola sumber daya fisik menjadi mengelola pengetahuan. 
Budi Astuti, Konsep Sistem Sinkronisasi Energi: Upaya Sistemik Optimalisasi Sumber...

Sampai-saat ini nilai organizational learning telah banyak dikenali. Manajer s memandang pengetahuan sebagai salah satu faktor atas asset korporat, menjadi pengungkit (leverage) dan dapat dieksploitir untuk maksud daya saing (Garvin, 2000:ix). Organizational knowledge creation adalah kemampuan suatu organisasi secara keseluruhan untuk menciptakan pengetahuan baru yang disebarluaskan keseluruh organisasi dan melingkupinya di dalam produk, jasa dan sistem (Nonaka, Takeuchi 1995:3). Menurut epistemologi; knowledge dibagi menjadi dua yaitu tacid knowledge dan explicit knowledge. Tacit knowledge adalah personal, content specific, oleh karena itu sukar diformalkan dan dikomunikasikan. Sementara explicit knowledge atau "codified" knowledge mengacu pada pengetahuan yang dapat disampaikan secara formal. Tacid knowledge mencakup elemen kognitif dan teknikal. Elemen kognitif berkaitan dengan mental model, seperti paradigma, keyakinan dan cara pandang. Elemen teknikal meliputi know-how, ketrampilan, kerajinan. Tacid knowledge individual merupakan basis organizational knowledge creation.

\section{KONSEP LEARNING ORGANIZATION}

Learning merupakan suatu hal penting bagi organisasi dikarenakan kontribusinya dalam langkah transisi atas aplikasi gagasan dan pembangkit gagasan-gagasan baru. Learning organization didefinisikan sebagai suatu organisasi yang trampil dalam penciptaan, pencarian, interpretasi, pentransferan dan penguasaan pengetahuan dan dengan kemauannya memodifikasi perilaku agar merefleksikan pada pengetahuan dan wawasan baru (Garvin, 2000:11). Sedangkan menurut Dibella et all (1996:364) yang dimaksud |organizational learning adalah suatu proses didalam organisasi untuk mempertahankan atau memperbaiki kinerja dengan mendasarkan pada pengalaman.

Learning mencakup akuisisi pengetahuan (pengembangan ketrampilan, wawasan, keterkaitan) "sharing" pengetahuan (diseminasi pengetahuan yang telah didapat kepada orang lain) dan pemanfaatan pengetahuan (integrasi pembelajaran sedemikian rupa sehingga terasimilasikan, secara luas tersedia/ mudah didapat, dan dapat pula digunakan pada situasi yang baru). Pembelajaran merupakan suatu cara bagi suatu organisasi untuk tumbuh dan memperbaharui dirinya sendiri (Bukowitz, Williams, 1999:129). Adalah|suatu proses pembelajaran yang menciptakan suatu budaya perbaikan berkelanjutan . Sementara itu learning organization memerlukan langkah|berani untuk mendorong sebanyak mungkin orang untuk take risk, inovatif dan keluar dari kebiasaan minta petunjuk dan menunggu instruksi. Didasari, bahwa risiko diperlukan guna.mendapatkan lompatan quantum dalam mutu produk dan jasa (Marquardt, 1997:71). Banyak organisasi/perusahaan menyadari bahwa kunci pertimbangan bisnis bukanlah kapital, personal, fasilitas, akan tetaṕi pengetahuan, informasi dan gagasan, banyaknya cara-cara baru dalam memandang organisasi (Marquardt, 1997:9).

? Pembelajaran menyangkut dua dimensi yaitu operasional dan konseptual. * Konseptual menyangkut pola pikir dan operasional berkaitan dengan action learning. Action learning mencakup keterlibatan pekerjaan dalam problem nyata, 
memfokuskan pada learning acquired dan mengimplementasikan solusi: Tidak ada learning tanpa action dan tidak ada action tanpa learning. Terdapat dua manfaat dari action learning, yaitu pertama, pengembangan ketrampilan dan pengetahuan melalui proses refleksi atas tindakan saat menyelesaikan problem, dan kedua, terjadinya perubahan bila partisan mengarahkan problem organisasi dalam perspektif baru. Kelompok non hirarki berasal dari berbagai departemen dan fungsi seringkali akan mendapatkan perspektif baru lebih baik (Marquardt, 1997:40). Oleh karena itu sinergi lintas fungsional dalam pembelajaran akan memberikan kontribusi pembelajaran yang lebih baik, karena akan melibatkan berbagai disiplin dan fungsi sehingga memberikan keluasan sudut pandang. Dengan demikian pembelajaran menyangkut dua arti yaitu: (1) akuisisi ketrampilan atau know-how, hal ini mengindikasikan kemampuan mengartikulasikan suatu pengertian konseptual atas suatu pengalaman. Dalam pembelajaran terdapat keterkaitan antara pemikiran dan tindakan. Sehingga learning didefinisikan sebagai peningkatan kapasitas seseorang untuk melakukan tindakan yang efektif (Kim, 1997:38).

Pemikiran manajemen dan teori organisasi saat ini menekankan tiga wilayah utama dimana. kreasi dan pemanfaatan informasi memainkan peran strategik dalam menentukan kapasitas organisasi untuk tumbuh dan berkembang: Pertama, organisasi memanfaatkan informasi untuk membuat sense of change dan pengembangan atas lingkungan eksternalnya. Kedua, penggunaan informasi strategik timbul manakala organisasi menciptakan, mengorganisasikan, dan memproses informasi demi kepentingan penumbuhan pengetahuan baru melalui organizational learning. Ketiga, penggunaan informasi strategik terjadi bila organisasi berupaya mencari dan mengevaluasi informasi untuk kepentingan pembuatan keputusan penting (Choo, 1998:1-2).

Kunci keberhasilan perusahaan/organisasi di Jepang adalah karena melakukan inovasi terus menerus, dan inovasi terus-menerus akan mengarah kepada keunggulan bersaing melalui knowledge creation. Organization knowledge creation adalah kemampuan suatu organisasi secara keseluruhan untuk menciptakan pengetahuan baru yang disebarluaskan keseluruh organisasi dan melingkupinya di dalam produk, jasa dan sistem (Nonaka \& Takeuchi, 1995:3). Dalam pengembangan learning organization diperlukan ketrampilan individual dan ketrampilan manajemen. Ketrampilan individual meliputi ketrampilan : komunikasi (oral, tertulis, mendengar), fleksibilitas, kreativitas, dan inovasi, fokus pelanggan, pengembangan produk dan proses, serta inisiatif. Sedang ketrampilan manajemen meliputi: pengelolaan dan pengembangan karyawan, keragaman perbedaan (diversity), team building, project management, relation influence. Inti learning organization adalah subsistem pembelajaran pada tingkat individu, kelompok, dan organisasi.

Visi organisasi yang jelas dan kualitas hubungan dengan industri, pasar dan masyarakat akan membantu dalam penyusunan agenda organisasi bagi pembelajaran dan pengembangan pengetahuan. Knowledge creation meningkatkan kapabilitas organisasi atas pengungkitan keahlian anggota-anggota organisasi, dan dengan pembelajaran dari dan dengan organisasi lain. Dalam memobilisasi pengetahuan internal, maka pemrosesan informasi dikelola untuk mempromosikan information sharing, konversi tacit knowledge, eksperimentasi, 
Budi Astuti, Konsep Sistem Sinkronisasi Energi: Upaya Sistemik Optimalisasi Sumber...

' dan migrasi pengetahuan ke bagian-bagian lain dalam organisasi (Choo, 1998:153). Knowledge creating bergantung pada tacit knowledge individual dan kelompok, serta keterkaitan knowledge dengan pengembangan internal dan eksternal organisasi. Hasil knowledge creating adalah inovasi atau ekspansi kapabilitas organisasi (Choo, 1998:220).

Menghadapi perubahan lingkungan yang begitu cepat diperlukan redefinisi perusahaan. Perusahaan/organisasi perlu memfokuskan perhatian kepada kunci asset knowledge yang merupakan kemampuan organisasi untuk melakukan inovasi. Organizational learning terjadi bila anggota organisasi tanggap terhadap perubahan lingkungan yaitu dengan cara pendeteksian kesalahan/masalah dan memperbaiki kesalahan/masalah melalui modifikasi strategi, asumsi, dan normanorma. Conseptual learning menimbulkan perubahan dalam kerangka pikir yang mengarah pada cara-cara baru dalam sudut pandang. Operational learning menghasilkan rutinitas baru atau rutinitas terbaharui yang menggantikan rutinitas lama. Mental model terbaharui tidak hanya menyangkut pola pikir baru dan rutinitas, akan tetapi juga berkenaan dengan kesesuaian rutinitas tersebut didalam pola pikir yang baru. Pola pikir inidividu akan menjadi terpatri di dalam weltanschauung organisasi.

Keinginan pelanggan adalah dinamis. Oleh karena itu kontak berkelanjutan dengan pelanggan merupakan suatu hal penting dalam total quality. Organisasi perlu mengetahui bagaimana pelanggan mendefinisikan nilai. Nilai suatu produk atau jasa merupakan penjumlahan dari persepsi pelanggan atás faktor-faktor: mutu produk/jasa, layanan yang diberikan oleh organisasi, personel organisasi, citra organisasi, harga produk/jasa.

Implementasi dan integrasi teknologi akan menghasilkan competitive advantage yang berasal dari adanya mutual adaptasi yaitu adạptasi teknologi ke lingkungan pengguna dan lingkungan pengguna terhadap teknologi. Namun demikian implementasi tersebut harus dikelola sebagai suatu proyek inovasi, sehingga pengetahuan tidak tertambat hanya di lokasi atau individu teitentu. Organisasi saat ini berada dalam suasana turbulen, perkembangan teknologi dan persepsi konsumen terhadap barang yang ditawarkan berubah dengan cepat. Untuk itu perusahaan perlu belajar dan mengabsorsi informasi dan pengetahuan yang berasal dari luar organisasi. Suatu hal yang kritis dalam inhovative capabilities adalah kemampuan organisasi mengenai nilai-nilai baru, informasi eksternal, mengasimilasikan dan menerapkannya sehingga berujung pada komersialisasi produk/jasa inovasi (Barton, 1995:136). Oleh karena itu perlu menyertakan "outsiders" ke dalam "in-house" dan pertukaran pengetahuan menjadi suatu hal yang mendesak.

\section{Aktivitas Kuncilnovasi}

Suatu perusahaan dalam menjaga dan mengembangkan daya saing perlu memfokuskan faktor aset pengetahuan yang dimiliki dan merupakan. kemampuan perusahaan untuk melakukan inovasi. Menurut Barton (1995:8) ada empat aktivitas pembelajaran yang menciptakan dan mengontrol 
pengetahuan yang diperlukan untuk operasi saat kini dan masa depan. Tiga aktivitas diantaranya terfokus secara internal yaitu: Pertama, shared creative problem solving (untuk menghasilkan produk saat kini). Kedua, implementasi dan integrasi metodologi dan tools baru (untuk meningkatkan operasi internal), dan ketiga, eksperimentasi formal dan informal (untuk membangun kapabilitas masa depan). Aktivitas keempat memfokuskan pada aspek eksternal yaitu menarik pengalaman dari dunia luar organisasi. Perbaikan berkelanjutan merupakan koreksi dan pengembangan terhadap prosedur atau cara-cara melaksanakan kegiatan. Pengetahuan hanya terdifusi manakala terdapat proses pembelajaran dimana karyawan mengembangkan kapasitas baru guna tindakan yang efektif(Senge, 1999:421). Ukuran keberhasilan atas pelaksanaan caracara baru dalam menyelesaikan suatu masalah perlu mendapat perhatian, agar pengalaman tersebut dapat menjadi refleksi bagi anggota organisasi lainnya.

Penyelesaian masalah bersama memerlukan keterbukaan atas batasbatas fungsional dan disiplin, sehingga terbentuk kelompok lintas fungsional dan lintas disiplin. Inovasi seringkali muncul daripengambilan gagasan berbagai disiplin. Pengalaman kelompok atas suatu masalah membutuhkan shared mental model agarmemungkinkan transfer tacit knowledge dan explicit knowledge ke segenap anggota organisasi. Kemampuan melakukan kolaborasidalam menyelesaikan masalah bersama dipengaruhi oleh ketrampilan individual.

Definisi eksperimen adalah suatu tindakan percobaan terhadap sesuatu atau mendapat suatu bukti, prosedur sementara, suatu metoda, suatu pilihan tindakan operasi yang dilakukan untuk mengungkapkan sesuatu yang tidak diketahui (Garvin, 2000:140). Organizational learning tidak hanya memerlukan penemuan produk/proses baru akan tetapi juga bagaimana mengadopsi dan memodifikasikan serta mendifusikan ke bagian-bagian lain organisasi dan kepada organisasi lain. Learning organization terampil atas lima aktivitas utama yaitu; penyelesaian masalah secara sistematik, eksperimentasi dengan pendekatan-pendekatan baru, belajar dari pengalaman masa lalu diri sendiri, belajar pengalaman dariorang lain, dan mentransfer pengetahuan secara cepat dan efisien ke seluruh organisasi (Garvin, 2000:282). Aktivitas eksperimen memunculkan dua macam kapabilitas baru. Pertama, eksperimen menimbulkan apa yang dinamakan dengan "requisite variety" dalam produk dan proses. Kedua, tindak eksperimen memungkinkan siklus inovasi. Dalam membangun iklim eksperimentasi maka perlu pemahaman dua hal penting dalam praktek tugas yaitu: pertama, memisahkan antara kegagalan intelektual dengan kegagalan yang tidak perlu, baik dari segi bahasa maupun tanggungjawab manajerial, dan kedua mengenali peran kegagalan di dalam pembangunan pengetahuan (Barton,1995:118). Kegagalan/kesalahan intelektual sebagai akibat dari risk taking, bila orang tidak berani mengambil risiko atas perkataannya atau mengerjakan sesuatu salah maka tidak ada ruang bagi kreativitas.

Persaingan dan tantangan teknologi yang dihadapi perusahaan di masa datang menuntut perusahaan beroperasi dalam kontek meluas dan holistic. Keberhasilan perusahaan akan ditentukan dari perspektif baru perusahaan itu sendiri terhadap pemahaman faktor-faktor yang menyokong perusahaan melampaui cara-cara tradisional dalam siklus produksi. Faktor-faktor tersebut meliputi keseluruhan aktivitas yang diawali dari permintaan pasar dan diakhiri 
Budi Astuti, Konsep Sistem Sinkronisasi Energi: Upaya Sistemik Optimalisasi Sumber...

\begin{tabular}{ll}
$\mid \begin{array}{l}\text { dengan kepuasan pelanggan. Hal ini membutuhkan pemikirah baru tentang } \\
\text { bagaimana berbagai elemen organisasi bekerja bersama, mengorganisasi, } \\
\text { bertindak, berhubungan, dan ukuran tentang nilai serta bagaimana } \\
\text { memotivasinya. }\end{array}$ \\
\hline E. SINKRONISASI ENERGI
\end{tabular}

Kata sinergi berasal dari bahasa Yunani yaitu synergos yang berarti bekerja bersama. Dalam pemakaian dunia bisnis, sinergi mengacu pada kemampuan dua atau lebih unit-unit atau perusahaan untuk membangkitkan nilai besar dengan bekerja bersama dari pada bekerja secara sendirian (Michael, 1998: 133). Unit-unit seringkali mendapat manfaat dari kegiatan berbagi pengetahuan dan ketrampilan. Sebagai misal mereka dapat me mperbaiki hasil dengan penyatuan wawasan-wawasan ke.dalam suatu bentuk proses khusus. Shared know-how dapat diwujudkan pada manual operasi, kebijakan, prosedur. Nilai dapat dengan mudah terbentuk dengan membuka dinding pembatas antar sekelompok orang yang mempunyai perbedaan tentang cara bagaimana melakukan sesuatu. Selain meningkatkan aliran know-how, sinergi juga ditujukan untuk mengurangi duplikasi serta kebiasaan buruk.

Bekerja dan belajar secara kelompok dipandang sebagai kunci untuk meningkatkan produktivitas dan kreativitas. Inovasi berkelanjutan merupakan usaha menggapai dan mengembangkan gagasan-gagasan baru Gagasan baru harus didifusikan keseluruh organisasi, mengembang dari individu ke individu lainnya, dari departeman ke departemen lainnya, dari divisi ke divisi lainnya. Menurut Senge (1999: 529 - 535) terdapat tiga elemen penting organisasi pembelajar demi keberhasilan pengembangan berkelanjutan, yaitu: shared vision and personal mastery, team learning and mental model, dan system thinking.

Organisasipada era industrimendasarkan pada spesialisasilsingle skilling (Clarke \& Clegg, 1998: 31). Dalam knowledge society yang|menjadi faktor penentu sumber daya adalah akses kepada pengetahuan, dengan jalan mengeksploitasi inovasi dan pengetahuan yang akan memberikan nilai tambah kepada perusahaan melalui optimalisasi manusia sebagai sumber daya kreativitas. Faktor utama yang menjadikan keberhasilan perusahaan Jepang adalah karena melakukan continuous innovation. Continuous innovation akan mengarah kepada keunggulan bersaing. Menggapai keberhasilan dan pembelajaran berkelanjutan, kunci suksesnya adalah kemauan untuk mempertahankan pembelajaran daripengalaman. Pengembangan berkelanjutan tidak dapat dicapai tanpa inovasi, dan inovasi hanya dapat dicapai didalam budaya yang menumbuh-kembangkan pembelajaran dan perubahan (Senge, 1999: 535). Beberapa pertimbangan dalam melakukan sinkronisasi energi adalah sebagai berikut:

1. Teamwork

Organisasi dengan manajemien tradișional memandang bahwa cara terbaik 
untuk usaha kompetitif seringkali berada diantara departemen-departemen di dalam suatu organisasi. Perlunya melakukan teamwork digambarkan sebagai perjuangan untuk memenangkan pertarungan yang tidak dapat dilakukan secara sepotong/terpisah dalam menghadapi rintangan, rival dan rasa ketidakpercayaan.

2. Proses Peningkatan Berkelanjutan

Produk atau jasa diciptakan melalui proses di dalam suatu sistem. Guna meningkatkan mutu produk atau jasa secara terus-menerus diperlukan perbaikan sistem secara terus-menerus pula.

3. Pendidikan dan Latihan

Pendidikan dan latihan merupakan cara terbaik untuk mengembangkan sumber daya manusia. Melalui pendidikan dan latihan manusia/orang tahu bagaimana belajar bekerja keras dan bagaimana pula bekerja bijak. Manajemen secara konstan mendorong para karyawan meningkatkan ketrampilan teknis dan keahlian professional.

4. Kebebasan dalam Pengawasan

Pemberdayaan dan pelibatan karyawan merupakan fundamental total quality, sebagai suatu cara membawa kesatuan pemikiran secara serempak dalam proses pengambilan keputusan dan meningkatkan perasaan memiliki.

5. Kesatuan Arah Tujuan

Manajemen dan karyawan dalam organisasi total quality harus mempunyai satu kesatuan tujuan. Hal ini berarti bahwa tidak ada ruang bagi berkembangnya politik internal, adanya kepentingan yang tidak searah dengan sasaran organisasi.

6. Pelibatan dan Pemberdayaan Karyawan

Dasar pelibatan karyawan mempunyai dua arti. Pertama, meningkatkan kecenderungan atas keputusan yang lebih baik, perencanaan lebih baik, atau membawa pemikiran dan situași yang mengakibatkan perbaikan lebih efektif. Kedua, mendorong rasa kepemilikan atas keputusan dengan keterlibatan bagi siapa saja yang akan melaksanakannya. Pemberdayaan bukan berarti sekedar melibatkan orang tetapi melibatkan mereka di dalam cara-cara yang memberikan mereka suatu real voice. Salah satu cara yang dapat dilakukan adalah dengan melakukan struktur pekerjaan yang memungkinkan karyawan membuat keputusan berkenaan dengan perbaikan proses kerja di dalam parameter yang telah terspesifikasi dengan baik. Kelompok fungsional internal bekerjasama saling berbagi dalam mencapai sasaran, kebiasaan dalam organisasi adalah belajar (dan menjalankan bilamana akan menghasilkan dalam perbaikan), siklus waktu penelitian dan pengembangan secara terus-menerus dikurangi, penyelesaian masalah dengan segera dan investasi ditanam dalam pengembangan gagasan inovatif. Pelibatan karyawan di dalam pembuatan keputusan yang berkaitan bidang kerja mereka merupakan prinsip dasar manajemen yang baik. Dalam total quality, karyawan tidak hanya terlibat dalam pengambilan keputusan tetapi juga dalam proses pemikiran kreatif yang mendahului pembuatan keputusan. Pandangan tradisional mengatakan bahwa bekerja keras/working hard dipandang menjamin keberhasilan. Akan tetapi dengan perkembangan kompetisi global dan kemajuan otomatisasi secara bersama-sama, maka 
Budi Astuti, Konsep Sistem Sinkronisasi Energi: Upaya Sistemik Optimalisasi Sumber...

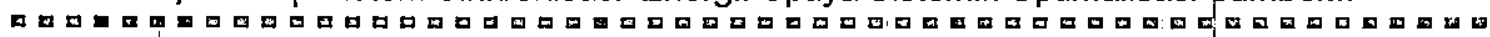

kunci menjadi tidak hanya bekerja keras tetapi juga working smart/bekerja pintar. Aspek working smart yang sering kali hilang dalam tempat-tempat kerja adalah pelibatan dan pemberdayaan karyawan|sedemikian rupa sehingga mendapat keunggulan atas kreativitas mereka dan mendorong pemikiran independen dan inisiatif. Pemikiran kreatif dan inisiatif yang berasal dari banyak karyawan akan memungkinkan kecenderungan lebih baiknya gagasan, keputusan, mutu, produktifitas dan daya saing. Pertanyaan yang muncul sebagai langkah mendapatkan perbaikan antara lain: "mengapa sesuatu dilaksanakan dengan cara sedemikian?" Dan "bagaimana sesuatu dapat dilaksanakan dengan baik?" Serta, akankah pelanggan menginginkan produk seperti itu?

Dalam proses mancarijawaban, mereka juga membangkitkan gagasan untuk solusi, lebih-lebih bila diberikesempatan untuk mendiskusikan secara teratur gagasan mereka di dalam suatu kelompok yang bersifat positif, suportif dan saling mengasuh. Penghambat utama pemberdayaan dan pelibatan adalah resistensidari karyawan dan manajemen terhadap perubahan.

Integrated enterprise menimbulkan suatu kerangka bagi resolusi keberhasilan, akan tetapi harus disertai dengan aliran informasi yang bebas, yang tidak dihalangi oleh rintangan budaya dan hambatan organisasi. Hambatan tersebut muncul bila tiap elemen perusahaan memandang dirinya sendiri sebagai satu kepentingan dan bukan sebagai cara untuk memenuhi kepentingan perusahaan yang lebih besar. Tantangan yang dihadapi adalah mengadopsi suatu struktur yang memungkinkan mengalirnya transformasi pengetahuan dan material kedalam penyelesaian masalah pelanggan, melalui model sinergi lintas fungsional.

Dalam proses pendidikan tinggi peran terbesar pembentuk output/ pelanggan adalah terletak pada jurusan/program studi/departemen. Jurusan dalam kerja kesehariannya akan berhubungan dengan bagian akademik, laboratorium akademik untuk pengembangan internal, dan juga dengan pusatpusat pengembangan.

Pengembangan produk nir lintas fungsional seperti terlihat pada Gambar: 1 merupakan model pengembangan produk yang biasa/kadangkala dilakukan dalam lingkup perguruan tinggi. Dari gambar tersebut nampak bahwa masing masing bagian mengembangkan produknya sendiri-sendiri, kadang kala diantara produk tersebut tidak mempunyai keterkaitan baik substansi maupun kemanfaatan, sehingga kecil kemungkinan akan terjadinyà interaksi diantara bagian tersebut untukmelakukan proses pembelajaran dalam pengembangan produk. 


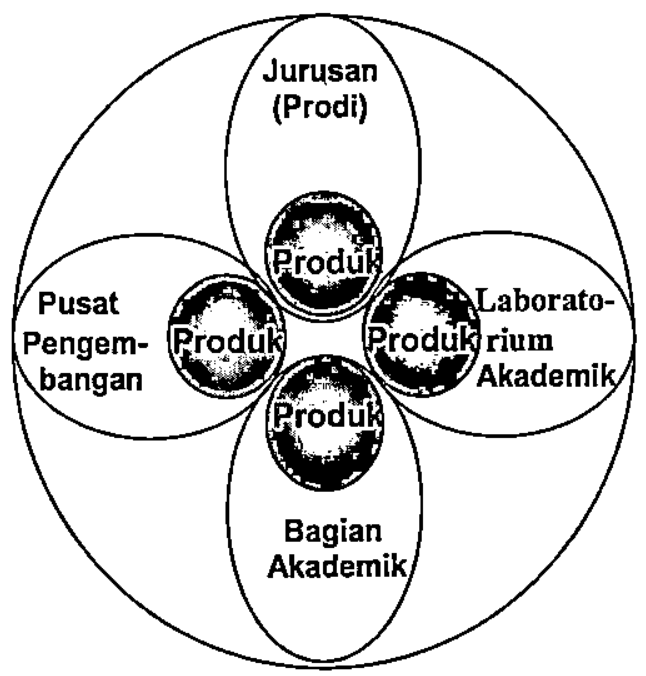

Gambar 1: Model Pengembangan Konsep Produk Nir-Lintas Fungsional Sumber: Gambar olahan, adaptasi dari konsep "sashimi" (Nonaka \& Takeuchi, 1995:78) dan konsep "concurrent engineering" (Heim, Compton. 1992:17)

Situasi krisis seperti sekarang menyebabkan organisasi harus berpikir ulang tentang penetapan anggarannya. Keterbatasan anggaran yang tersedia serta perubahan kebijakan akibat adaptasi terhadap perubahan lingkungan, mendorong pada usaha-usaha optimalasi sumberdaya yang ada. Usaha tersebut dilakukan dengan merencanakan kegiatan yang bisa saling mengisi, seperti tergambarkan pada Gambar: 2.

Pada dunia pendidikan tinggiperan terbesar pembentuk output/pelanggan adalah terletak pada program studi/jurusan/departemen. Jurusan yang terdiri dari para kelompok pengajar akan menjadi lokomotif yang menentukan hasil proses/output. Jurusan dengan aset utamanya sumber daya manusia hendaknya selalu berpikir cerdas untuk selalu mengembangkan kurikulum, silabus dan atau metode proses belajar mengajar yang unik. Sementara itu agar aset ini menjadi handal, kualified maka secara internal dapat dikembangkan melalui kerja bersama dengan laboratorium akademik, sedangkan untuk pengembangan yang ke arah eksternal dapat dilakukan bersama-sama dengan pusat-pusat pengembangan yang dimilikinya. Adapun untuk proses adminitrasi akademik perlu kerja bersama dengan bagian akademik.

Dengan melakukan pengembangan produk seperti terlihat pada model pengembangan produk lintas fungsional, telah terbuktimenghasilkan perbaikan kinerja, serta efisiensi dan efektifitas pencapaian hasil. Pengalaman atau 
Budi Astuti, Konsep Sistem Sinkronisasi Energi: Upaya Sistemik Optimalisasi Sumber...

pembelajaran yang didapat dari pelaksanaan pengembangan produk dengan cara tersebut semestinya dapat merupakan inspirasibagi organisasi pendidikan tinggi untuk menjadikannya sebagai pengungkit perbaikan kinerja organisasi.

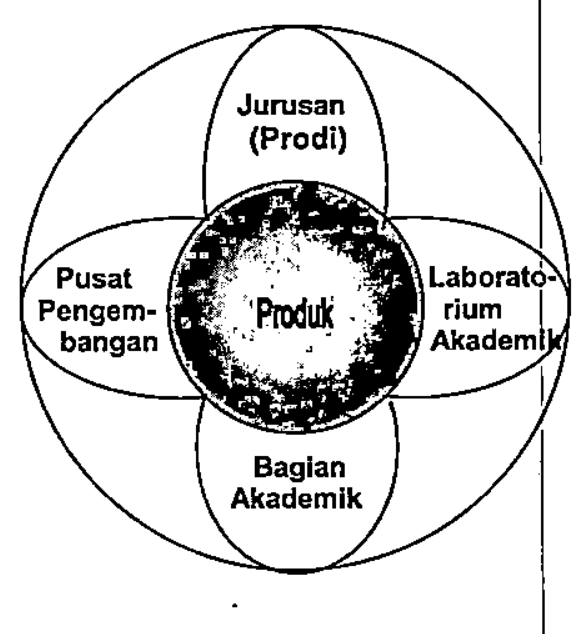

\section{Fungsional}

Gambar 2: Model Pengembangan Konsep Produk Sinergi Lintas

Sumber: Gambar olahan, adaptasi dari konsep "sashimi" (Nonaka \& Takeuchi, 1995:78) dan konsep "concurrent engineering" (Heim, Compton. 1992:17)

Manfaat yang diperoleh dari kegiatan tersebut menurut mereka yang terlibat dalam 'team lerning' adalah:

1. Sharing data/informasi

Dalam melakukan kegiatan tidak perlu masing-masing bagian mencari data sendiri-sendiri yang diperiukan untuk melaksanakan kegiatan ditiap bagian Aktivitas berbagi data dan informasi sangat mempermudah pelaksanakan pekerjaan.

2. Kebersamaan

Kekurangan dan kelebihan bisa dipertukarkan dengan adanya keterbukaan sebagai akibat adanya 'overlapping'.

3. Penguasaan Ketrampilan

Pengetahuan dan ketrampilan terdesiminasi keseluruh kelompok tidak terhenti pada personal/bagian tertentu, pada akhirnya hampir semua yang terlibat mempunyai ketrampilan dikarenakan proses pembelajaran dan adanya ketergantungan dengan bagian lain.

4. Potensi Konflik/Kepentingan

Perbedaan kepentingan yang memicu pada konflik terbuka ternyata tidak muncul seperti apa yang mungkin terbayangkan bila melakukan kegitan “overlapping". Orang mulai belajar bagaimana mengelola perbedaan. 


\section{G. PENUTUP}

Mengingat kondisi persaingan yang semakin kompetitif dalam semua bidang tidak terkecuali bidang pendidikan, maka sudah sepantasnyalah organisasi pendidikan sebagai pencetak penerus bangsa untuk selalu melakukan continuous improvement. Salah satu upaya yang dapat dilakukan adalah melalui konsep sinkronisasi energi.

Dengan melaksanakan konsep tersebut jelas akan diperoleh banyak manfaat seperti yang telah diuraikan di atas yang pada akhirnya bermuara dengan tercapainya efisiensi dan efektivitas kerja serta perbaikkan kinerja. 
Budi Astuti, Konsep Sistem Sinkronisasi Energi: Upaya Sistemik Optimalisasi Sumber...

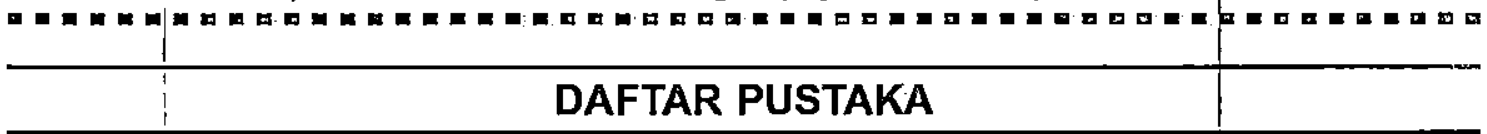

Alan Burton Jones (1999), Business, Work, and Learning in The New Economy, Knowlegde Capitalism, Oxford University Press.

Bukowitz WR, Williams R (1999), The Knowledge Management Fieldbook, Pearson Education Limited.

Choo CW (1998), The Knowing Organization: How Organization Use Information To Construct Meaning, Creative Knoledge And Make Decision, Oxford. University Press.

Clarke T, Cleeg S (1998), Changing Paradigms, The Transformation of Management Knowledge For The $21^{1 t}$ Century.

Dibella J, A., Nevis, EC, Gould, JM (1996), Understanding Organizational Learning Capability, Journal of Management Studies Volume 33 No: 3 May 1996, Blackwell Publisher, Oxford, UK and Cambridge USA.

Dorothy, Leonard, Barton (1995), Wellspring Knowledge, Building and Sustaining The Source of Innovation, Harvard Business School Press, Boston.

Garvin, David A(2000), Building A Learning Organization, dalam Organization Development and Trasformation, French WL, Bell CH, Zawachi RA(Editor), Mc Graw Hill, Boston.

(2000), Learning in Action, A guide to Putting The Learning Organization to Work, Harvard Business School Press, Boston.

Gilley JW, Maycunichi A (2000), Beyond The Learning Organization: Creating a Culture of Continuous Growth and Development Through State -of-Art Human Resource Practise, Perseus Book, Cambridge!

Linsu Kim (1997), Imitation To Innovation, The Dynamic of Korea's Technological Learning, Harvard Business School Press, Boston.

Marquardt MJ (1997), Building The Learning Organization, A System Approach to Quantum Improvement and Global Success, Mc Graw Hill, New York.

Michael, Andrew Camphell, (1998), Desperetly Seeking Synergy, Harvard Business Review, September-October.

Nonaka, l., Takeuchi H , (1995), The Knowledge Creating Company: How Japanese Companies Create The Dynamics of Innovation, Oxford University Press, New York.

Senge P, Anet K, Charlote R, Richard R, George R, Bryan S (1999), The Dance of Change: The Chalengs of Sustaining Momentum in Learning Organization, Doubledary, New York. 